\title{
Efficient and Convenient Route for the Synthesis of Some New Antipyrinyl Monoazo Dyes: Application to Polyester Fibers and Biological Evaluation
}

\author{
Ahmed A. Fadda and Khaled M. Elattar \\ Department of Chemistry, Faculty of Science, Mansoura University, Mansoura 35516, Egypt \\ Correspondence should be addressed to Khaled M. Elattar; khaledelattar2@yahoo.com
}

Received 25 June 2012; Revised 29 October 2012; Accepted 17 November 2012

Academic Editor: M. Akhtar Uzzaman

Copyright (C) 2013 A. A. Fadda and K. M. Elattar. This is an open access article distributed under the Creative Commons Attribution License, which permits unrestricted use, distribution, and reproduction in any medium, provided the original work is properly cited.

\begin{abstract}
Nine variously substituted azo dye derivatives 2-10 of antipyrine were prepared. The effects of the nature and orientation of the substituents on the color and dyeing properties of these dyes for polyester fibers were evaluated. The newly synthesized compounds were characterized on the basis of elemental analyses and spectral data. On the other hand, the investigated dyes were applied to polyester fabrics and showed good light, washing, heat, and acid perspiration fastness. The remarkable degree of brightness after washings is indicative of the good penetration and the excellent affinity of these dyes for the fabric. The results in general revealed the efficiency of the prepared compounds as new monoazo disperse dyes. The newly synthesized compounds were screened for their antioxidant and cytotoxic activity against Vitamin $\mathrm{C}$ and 5-fluorouracil, respectively. The data showed clearly that most of the compounds exhibited good antioxidant and cytotoxic activities.
\end{abstract}

\section{Introduction}

In recent years, there has been increasing interest in syntheses of heterocyclic compounds that have biological and commercial importance. Antipyrine compounds play an important role in modern organic synthesis, not only because they constitute a particularly useful class of heterocyclic compounds $[1-3]$, but also because they are of great biological interest. They have been found to have biological [4], clinical [5], and pharmacological $[6,7]$ activities. One of the most important derivatives of antipyrine is 4-aminoantipyrine, which is used as a synthetic intermediate to prepare polyfunctionally substituted heterocyclic moieties with anticipated biological activity [8], analgesic $[9,10]$, anti-inflammatory [10], antimicrobial [11-13], and anticancer [14] activities. It was of interest to study the reactivity of antipyrinylhydrazonomalononitrile towards different nitrogen nucleophiles as well as activated nitriles.
Considerable studies have been devoted to azo dyes derived from 4-aminoantipyrine [15-19]. Fadda et al. [2024] have reported the synthesis of different azo disperse dyes for synthetic fibers. Recently, other studies reported the application of synthesized azo dyes to polyester fabrics [25-27]. Thus, we have initiated a program of applying the synthesized dyes derived from 4-aminoantipyrine to polyester as disperse dyes to study their color measurement and fastness properties.

We aim to synthesize a series of new dyes derived from 4aminoantipyrine to apply these new dyes to polyester fabrics with the hope to get excellent fastness results.

\section{Results and Discussion}

2.1. Chemistry. The synthetic strategies adopted to obtain the target compounds are depicted in Scheme 1. The 
<smiles>Cc1c(N)c(=O)n(-c2ccccc2)n1C</smiles><smiles>Cc1c([N+]=[Cl+])c(=O)n(-c2ccccc2)n1C</smiles><smiles>CCOC(=O)[N+]([O-])(OCC)C(=O)OCC</smiles><smiles>Cc1c(NN=C(C#N)C#N)c(=O)n(-c2ccccc2)n1C</smiles>
2 $\downarrow \begin{gathered}\mathrm{RH} \\ \text { EtOH, reflux }\end{gathered}$<smiles>[R]/C(N)=C(/C#N)N=Nc1c(C)n(C)n(-c2ccccc2)c1=O</smiles>
$[1,5] \mathrm{H}$ migration

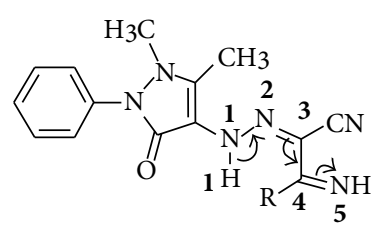

3-10

(3) $\mathrm{R}$<smiles></smiles><smiles>[14C]N1CCOCC1</smiles>

(5) $\mathrm{R}$<smiles>CN(C)CC(O)[C@H](O)[C@@H](O)[C@H](O)CO</smiles>

(6) $\mathrm{R}=$

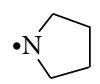

(7) $\mathrm{R}=$

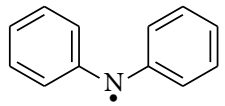

(8) $\mathrm{R}=$<smiles>C=O</smiles><smiles>C=C(CNc1ccc(Cl)cc1)OCC</smiles>

(9) $\mathrm{R}=$<smiles>CN1CCNCC1</smiles>

(10) $\mathrm{R}=$<smiles>CN1CCN(c2ccccc2)CC1</smiles>

SCHEME 1: A synthetic route for the preparation of acyclic enaminonitriles 3-10.

diazonium salt of 4-aminoantipyrine undergoes a coupling reaction with malononitrile in ethanolic sodium acetate solution at $0-5^{\circ} \mathrm{C}$ to give (1,5-dimethyl-3-oxo-2phenyl-2,3-dihydro-1H-pyrazol-4-yl)carbonohydrazonoyl dicyanide (2) [28]. Compound 2 reacted with different secondary amines namely, piperidine, morpholine, piperazine, pyrrolidine, diphenyl amine, ethyl 2-(4-chlorophenylamino)acetate, $N$-methylglucamine, and 1phenylpiperazine in refluxing ethanol to afford the corresponding $1: 1$ acyclic enaminonitrile adducts 310, respectively. The formation of enaminonitrile derivatives 3-10 was illustrated through the initial addition of the secondary amines to the cyano function to form the imino form followed by $[1,5] \mathrm{H}$ migration to form the enamine form. The general structural formula for dyes $\mathbf{2 - 1 0}$ is as shown in Scheme 1.

The structures of enaminonitriles 3-10 were assessed by elemental analyses and spectral data. The IR spectra exhibited absorption bands due to stretching vibrations of the $\mathrm{NH}_{2}$ group within $v=3450-3301 \mathrm{~cm}^{-1}$ and $v=2186-2171 \mathrm{~cm}^{-1}$ due to $\mathrm{CN}$ functions and $v=1648-1610 \mathrm{~cm}^{-1}$ due to carbonyl groups. The ${ }^{1} \mathrm{H}-\mathrm{NMR}$ spectrum of compound 3 revealed the presence of three multiplet signals at $\delta 1.58-1.69$, $3.52-3.62$, and $7.31-7.52 \mathrm{ppm}$ attributable to $\left(3 \mathrm{CH}_{2}\right.$, piperidine), $\left(2 \mathrm{CH}_{2}\right.$, piperidine), and aromatic protons, revealed two singlet signals at $\delta 2.63$ and $3.16 \mathrm{ppm}$ due to methyl and $N$-methyl protons, respectively, and amino protons appeared at $\delta 7.13 \mathrm{ppm}$ as broad singlet signal. The ${ }^{13} \mathrm{C}$ NMR spectra revealed signals due to the cyano group within $\delta=114.8-114.3$ ppm. Furthermore, the detailed ${ }^{1} \mathrm{H}-\mathrm{NMR}$ and ${ }^{13} \mathrm{C}$-NMR spectra for each compound were mentioned in the Experimental section. Moreover, the mass spectroscopic measurements of compounds 3-5 and 8-10 showed the molecular ion peaks at $\mathrm{m} / z 367\left(\mathrm{M}^{+}, 12.3\right), 368\left(\mathrm{M}^{+}-1,6.7\right)$, $477\left(\mathrm{M}^{+}, 100.0\right), 495\left(\mathrm{M}^{+}, 17.5\right), 368\left(\mathrm{M}^{+}, 11.4\right)$, and $444\left(\mathrm{M}^{+}\right.$, $5.0)$, respectively, which are equivalent with the molecular formula of the proposed structures (Figure 1).

However, no details regarding the dyeing behavior of these compounds as disperse dyes for dyeing polyester fibers have been reported.

\subsection{Dyeing of Polyester Fabrics and Dyeing Properties}

2.2.1. Color Measurement. On textiles, $K$ (the measure of the light absorption) is determined primarily by the dyestuffs and $S$ (the measure of the light scattering) only by the substrate. From the wave length Kubelka and Munk calculate the following relationship for reflectance $R$ of thick, opaque sample with the constant of " $K$ " and " $S$ ":

$$
\frac{K}{S}=\frac{(1-R)_{2}}{2 R}
$$




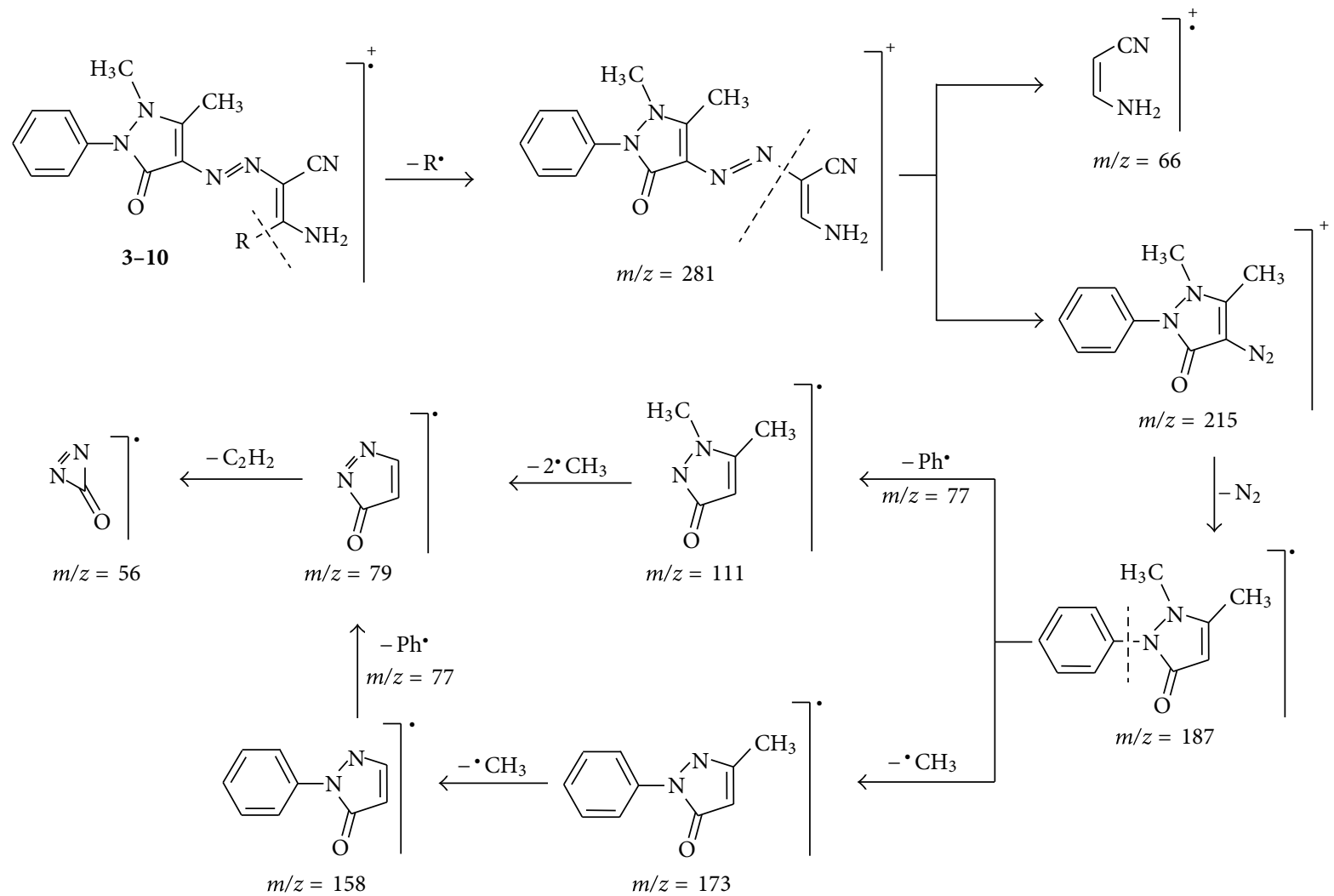

Figure 1: The general fragmentation pattern of 3-amino-3-substituted-2-[(1,5-dimethyl-3-oxo-2-phenyl-2,3-dihydro-1H-pyrazol-4yl)diazenyl] acrylonitrile derivatives 3-10.

The parent dyestuff 2 is taken as the standard in color difference calculation $\left(\Delta L^{*}, \Delta C^{*}, \Delta H^{*}\right.$, and $\left.\Delta E\right)[20,24,29]$.

The values of $K / S$ of compounds $\mathbf{2 - 1 0}$ vary from 0.43 to 2.70. The introduction of $N$-methylglucamine, pyrrolidine, piperazine, and $N$-phenyl piperazine moieties in dyes $5,6,9$, and 10, respectively, increase, the strength of $K / S$ value and deepens the color compared with the parent dye $\mathbf{2}$ (Table 1 ).

All dyes with +ve $\Delta C$ values and are brighter than the parent dye 2 .

All dyes with - ve $\Delta L$ values and are darker than the parent dye 2 . The positive value of $a^{*}$ and $b^{*}$ indicates that all groups shift the color hues of the dye to reddish direction on the redgreen axis and to the yellowish direction in the yellow-blue axis, respectively.

2.2.2. Assessment of Color Fastness. Most influences that can affect fastness are light, washing, heat, perspiration, and atmospheric pollution. Conditions of such tests are chosen to correspond closely to treatments employed in manufacture and of ordinary use conditions [30]. Results are given after usual matching of tested samples against standard reference (the gray scale) [30]. The results revealed that these dyes have good fastness properties (Table 2).

2.2.3. Dyebath Reuse. It has been found in conventional dyeing that after dyeing, only the dye and few of the specialty chemicals get fully consumed during the operation, while most of the chemicals remaining in the dyebath are rejected. Increasingly due to tough environmental guidelines, the dye houses have been forced to study the feasibility of dyebath reuse. The dyebath reuse depends on a number of factors like dye, shade, color, and if dyeing is carried out in a continuous or batch process. It has been found that in some cases, with a plan in place dyebaths can be successfully reused at least 5-25 times.

2.2.4. Development of the Reuse System. The procedure recommended by $\mathrm{Du}$ Pont for dyeing by adjusting $\mathrm{pH}$ from 3.5 to 4.0 with acetic acid. In the dyebath reuse procedure, at step 12 (Table 3), instead of dropping the bath to the drain, it is pumped to a holding tank. A sample of the spent bath is collected for analysis immediately before pumping to the holding tank. The fabric is rinsed and scoured in the dyeing machine by the usual procedure and then removed for drying. At the beginning of the next cycle, the dyebath is returned to the dyeing machine from the holding tank. Make-up water is added to compensate for the liquid retained by the fabric and the dyeing procedure continued as indicated in Table 3 . The quantities of auxiliaries and dyes shown by the analysis to be required for reconstitution of the bath are added at steps 3,5 , and 8 (Table 3 ). The only change required is that all the dyeing salt in step 7 is added at one time (the quantity required for a reuse dyeing cycle was usually less than $20 \%$ of the amount needed for a conventional dyeing cycle). 
TABLE 1: Optical measurements of compounds 2-10.

\begin{tabular}{lcccccccccccc}
\hline Dye & $R \%$ & $a^{*}$ & $b^{*}$ & $L^{*}$ & $C^{*}$ & $H^{*}$ & $\Delta L$ & $\Delta C$ & $\Delta H$ & $\Delta E$ \\
\hline $\mathbf{2}$ & 56.11 & -0.48 & 5.03 & 88.96 & 5.05 & 95.44 & - & - & - & - & - \\
$\mathbf{3}$ & 35.78 & 4.48 & 12.63 & 78.49 & 13.4 & 70.47 & -10.47 & 8.35 & -24.97 & 28.33 & 1.15 \\
$\mathbf{4}$ & 36.41 & -3.59 & 12.87 & 8.09 & 13.36 & 105.58 & -80.87 & 8.31 & 10.14 & 81.93 & 1.11 \\
$\mathbf{5}$ & 22.34 & -4.67 & 18.42 & 86.57 & 19.0 & 104.24 & -2.39 & 13.95 & 8.80 & 16.67 & 2.70 \\
$\mathbf{6}$ & 30.37 & -4.73 & 13.8 & 87.57 & 14.59 & 108.92 & -1.39 & 9.54 & 13.48 & 16.57 & 1.60 \\
$\mathbf{7}$ & 52.43 & -1.19 & 4.98 & 87.98 & 5.12 & 103.39 & -0.98 & 0.07 & 7.95 & 8.01 & 0.43 \\
$\mathbf{8}$ & 52.43 & -0.96 & 6.10 & 88.03 & 6.18 & 98.94 & -0.93 & 1.13 & 3.50 & 3.79 \\
$\mathbf{9}$ & 28.68 & 4.30 & 13.08 & 76.93 & 13.77 & 71.80 & -12.03 & 8.72 & -23.64 & 27.92 & 1.77 \\
$\mathbf{1 0}$ & 32.43 & 3.89 & 13.34 & 81.85 & 13.9 & 73.75 & -7.11 & 8.85 & -21.69 & 24.48 & 1.41 \\
\hline
\end{tabular}

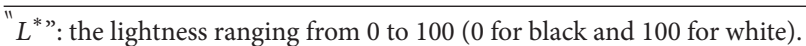

" $a$ "": the red-green axis, (+) for red, zero for gray, and (-) for green.

" $b$ "): the yellow-blue axis, (+) for yellow, zero for gray, and (-) for blue.

TABLE 2: Fastness properties of compounds 2-10.

\begin{tabular}{|c|c|c|c|c|c|c|c|}
\hline \multirow{2}{*}{ Dye } & \multirow{2}{*}{$\begin{array}{c}\text { Washing } \\
75^{\circ} \mathrm{C}\end{array}$} & \multicolumn{2}{|c|}{ Rubbing } & \multicolumn{2}{|c|}{ Sublimation } & \multirow{2}{*}{$\begin{array}{c}\text { Acid } \\
\text { perspiration }\end{array}$} & \multirow{2}{*}{$\begin{array}{c}\text { Light } \\
4 \mathrm{~h}\end{array}$} \\
\hline & & Dry & Wet & $180^{\circ} \mathrm{C}$ & $210^{\circ} \mathrm{C}$ & & \\
\hline 2 & $3-4$ & $4-5$ & 4 & $4-5$ & 4 & $4-5$ & $7-8$ \\
\hline 3 & $4-5$ & $4-5$ & 4 & 4 & 4 & $4-5$ & 7 \\
\hline 4 & $4-5$ & $4-5$ & $4-5$ & $4-5$ & 4 & $4-5$ & 7 \\
\hline 5 & $4-5$ & $4-5$ & $4-5$ & $4-5$ & 4 & $4-5$ & $7-8$ \\
\hline 6 & $4-5$ & $4-5$ & 4 & 4 & 4 & $4-5$ & $7-8$ \\
\hline 7 & $4-5$ & $4-5$ & $4-5$ & $4-5$ & 4 & $4-5$ & $7-8$ \\
\hline 8 & $4-5$ & $4-5$ & 4 & $4-5$ & 4 & $4-5$ & 7 \\
\hline 9 & $4-5$ & 4 & 4 & 4 & 4 & $4-5$ & $7-8$ \\
\hline 10 & $4-5$ & $4-5$ & $4-5$ & $4-5$ & 4 & $4-5$ & 7 \\
\hline
\end{tabular}

2.2.5. Analysis for Residual Dyes. The very strong absorption of dyes in the visible region of the spectrum provides the simplest and most precise method for the determination of dye concentrations. The absorbance $A$ of a dye solution can be related to the concentration by the modified Lambert-Beer equation

$$
A=\log \frac{I_{o}}{I}=K c
$$

where $I_{o}$ is the intensity of the visible radiation falling on the sample, $I$ is the intensity of the radiation transmitted by the sample, $K$ is a constant including the path length of radiation through the sample and a constant related to the absorptivity of the sample at a given wavelength, and cis the concentration of the absorbing species. In mixtures of absorbing species, the absorbance at any wavelength is the sum of the absorbanceS of each absorbing species and is given by

$$
A=K_{1} c_{1}+K_{2} c_{2}+K_{3} c_{3}+\cdots K_{n} c_{n} .
$$

The additive characteristic of light absorption by dyes is important in the analysis of dye mixtures of the type found in spent dyebaths. For such dye mixtures, the absorbance can be measured at a number of wavelengths and the concentrations of the dyes determined by simultaneous solution of a set of linear equations of the type shown above. The wavelengths selected for the analysis are generally those for which one of the dyes has a maximum in absorbance.

A further advantage of spectrophotometers is the ready availability of a number of low-cost instruments with sufficient accuracy and reproductivity for dyebath analysis. The computations required for the analysis can be conveniently carried out on low-cost desk calculators or microprocessors. Two major problems require solution before the use of spectrophotometry for residual dyebath analysis. Some dyes are not completely in solution and therefore do not follow the Lambert-Beer equations. Many dyebaths also show significant turbidity or background absorption which interferes with analyses based on attenuation of a light beam passing through the sample. In the current work, both of these problems were circumvented by extracting the dye from the dyebath sample into an organic solvent.

\section{Biological Evaluation}

3.1. ABTS Antioxidant Activity Screening. The antioxidant activity assay employed here is one of several assays that 
TABLE 3: The recommended dyeing procedure.

\begin{tabular}{|c|c|}
\hline Steps & Dyeing processes \\
\hline 1 & Fill dyeing machine \\
\hline 2 & Load fabric \\
\hline 3 & Add to bath at $38^{\circ} \mathrm{C}$ \\
\hline 4 & Run for $5 \mathrm{~min}$ \\
\hline 5 & Add the dyes \\
\hline 6 & Run for $5 \mathrm{~min}$ \\
\hline 7 & Add in three parts over $20 \mathrm{~min}$ \\
\hline 8 & Adjust $\mathrm{pH}$ to 3.5 to 4.0 with acetic acid \\
\hline 9 & Raise to $121^{\circ} \mathrm{C}$ \\
\hline 10 & Run for $1 \mathrm{~h}$ at $121^{\circ} \mathrm{C}$ \\
\hline 11 & $\begin{array}{l}\text { Cool to } 66^{\circ} \mathrm{C} \text { and sample; dye added } \\
\text { should be run at least } 1 \mathrm{~h} \text { at } 121^{\circ} \mathrm{C} \text { to } \\
\text { insure penetration }\end{array}$ \\
\hline 12 & Cool to $49^{\circ} \mathrm{C}$ and drop bath \\
\hline 13 & Rinse clear at $49-54^{\circ} \mathrm{C}$ \\
\hline \multicolumn{2}{|r|}{ After scour } \\
\hline 14 & $\begin{array}{l}\text { Set bath at } 40^{\circ} \mathrm{C} \text { with glacial acetic acid } \\
0.5 \mathrm{~g} / \mathrm{L} \text {. }\end{array}$ \\
\hline 15 & Raise to $82^{\circ} \mathrm{C}$ \\
\hline 16 & Run for $15 \mathrm{~min}$ \\
\hline 17 & Rinse clear at $40-54^{\circ} \mathrm{C}$ \\
\hline 18 & Check for crocking, extract, and dry \\
\hline
\end{tabular}

depend on measuring the consumption of stable free radicals, that is, evaluate the free radical scavenging activity of the investigated component. The methodology assumes that the consumption of the stable free radical $\left(X^{\prime}\right)$ will be determined by reactions as follows: $X H+Y^{\prime} \rightarrow X^{\prime}+Y H$.

The rate and/or the extent of the process measured in terms of the decrease in $X^{\prime}$ concentration would be related to the ability of the added compounds to trap free radicals. The decrease in color intensity of the free radical solution due to scavenging of the free radical by the antioxidant material is measured calorimetrically at a specific wavelength. The assay employs the radical cation derived from $2,2^{\prime}$-azinobis(3-ethylbenzthiazoline-6-sulfonic acid) (ABTS) as stable free radical to assess antioxidant potential of the isolated compounds and extracts. The advantage of ABTS-derived free radical method over other methods is that the produced color remains stable for more than one hour and the reaction is stoichiometric.

The antioxidant activity of some newly synthesized compounds was evaluated by the ABTS method [31]. The data in Table 4 showed clearly that compounds 2-7 and 10 exhibited good antioxidant activities, while compounds $\mathbf{8}$ and $\mathbf{9}$ have moderate to low antioxidant activity compared with Vitamin C. By comparing the results obtained by the antioxidant of the compounds reported in this study to their structures, the following structure activity relationships (SARs) were postulated: compounds $\mathbf{2 - 7}$ and $\mathbf{1 0}$ were nearly potent to "Vitamin C" which may be attributed to the presence of amino and imino groups which trap the free radical "X." On the other hand, incorporation of ester or sugar moieties to enaminonitrile chain reduces the antioxidant activity. Thus, it would appear that introducing an enaminonitrile moiety enhances the antioxidant properties of aminoantipyrine derivatives.

3.2. Cytotoxic Activity. Consequently and due to possible enhancement of biological activity resulting from the attachment of an antipyrine moiety to different enaminonitriles, our direction was attracted to the synthesis of new antipyrine derivatives as well as their analogs using this heterocyclic ring system as a nitrogen base. These derivatives, compared with their parent compound, displayed significant antioxidant and anticancer activities (Table 4) against Vero cells: cells from the kidney of green monkey; WI: fibroblast cells; HepG2: hepatoma cells, and MCF-7: cells from breast cancer (Figure 2).

Compounds 2-7 and 10 showed the strong cytotoxic activities compared with 5-fluorouracil (5-Fu). From the structure activity relationships (SARs), it is noteworthy that compounds 2-7 and $\mathbf{1 0}$ have $\mathrm{NH}_{2}$ groups that are effective in inhibiting cell damage. Compounds $\mathbf{8}$ and $\mathbf{9}$ showed weak activities compared with 5-fluorouracil, and this may be is due to incorporation of ester or sugar moieties to the antipyrine compounds.

\section{Conclusion}

It seems to be interesting for testing the dyeing behavior of antipyrine compounds for dyeing polyester fibers by convenient route for some new azo disperse dyes. Optical measurements and fastness properties were investigated. Nine useful disperse dyes $\mathbf{2 - 1 0}$ were synthesized by diazo coupling of 4-aminoantipyrine with malononitrile followed by addition of different secondary amines to the obtained coupling product. The dyes $\mathbf{2 - 1 0}$ were investigated for their dyeing characteristic on polyester and showed good light, washing, heat and acid perspiration fastness. The remarkable degree of brightness after washings is indicative of the good penetration and the excellent affinity of these dyes for the fabric due to the accumulation of polar groups. The results in general revealed the efficiency of the prepared compounds as new azo dyes. The newly synthesized compounds were screened for their antioxidant and cytotoxic activity against Vitamin C and 5-fluorouracil, respectively. The data showed clearly that most of the compounds exhibited interesting antioxidant and cytotoxic activities.

\section{Experimental}

5.1. Synthesis. All melting points are recorded on a Gallenkamp electric melting point apparatus. The IR spectra $v \mathrm{~cm}^{-1}(\mathrm{KBr})$ were recorded on a Perkin Elmer Infrared Spectrophotometer Model 157 Grating. The ${ }^{13} \mathrm{C}-\mathrm{NMR}$ and ${ }^{1} \mathrm{H}-\mathrm{NMR}$ spectra were run on a Varian Spectrophotometer at 100 and $400 \mathrm{MHz}$, respectively, using tetramethylsilane (TMS) as an internal reference and using dimethyl sulfoxide 
TABLE 4: Percentage viability of tested compounds on different cell lines.

\begin{tabular}{|c|c|c|c|c|c|c|}
\hline \multirow{2}{*}{ Compound } & \multirow{2}{*}{$\begin{array}{l}\text { Concentration } \\
(10-1000 \mu \mathrm{g} / \mathrm{ml})\end{array}$} & \multirow{2}{*}{$\begin{array}{c}\text { ABTS } \\
\text { Inhibition \% }\end{array}$} & \multicolumn{4}{|c|}{$\%$ viability } \\
\hline & & & HepG2 & WI 38 & VERO & MCF 7 \\
\hline 2 & 20 & 72.45 & 38 & 42 & 38 & 34 \\
\hline 3 & 20 & 76.64 & 39 & 49 & 38 & 35 \\
\hline 4 & 20 & 78.04 & 38 & 47 & 56 & 49 \\
\hline 5 & 20 & 79.04 & 59 & 42 & 45 & 41 \\
\hline 6 & 20 & 70.26 & 55 & 56 & 49 & 44 \\
\hline 7 & 20 & 79.04 & 38 & 42 & 45 & 42 \\
\hline 8 & 20 & 28.54 & 100 & 100 & 100 & 100 \\
\hline 9 & 20 & 40.91 & 75 & 83 & 100 & 84 \\
\hline 10 & 20 & 73.01 & 100 & 100 & 100 & 100 \\
\hline Vitamin C & $2 \mathrm{mM}$ & 80.03 & - & - & - & - \\
\hline 5-Fu & 20 & - & 8 & 4 & 12 & 18 \\
\hline
\end{tabular}

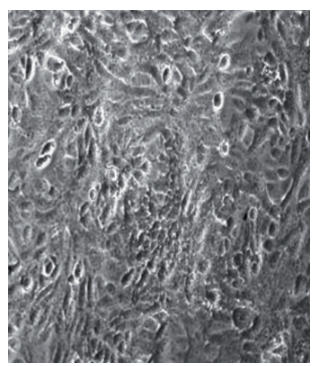

Vero cells

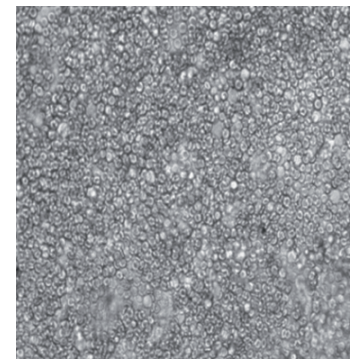

WI 38

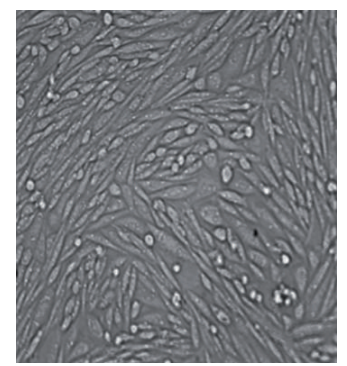

HepG2

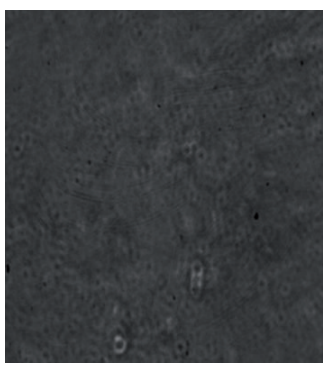

MCF-7

FIGURE 2: Confluent monolayers of cell lines used for testing.

(DMSO- $d_{6}$ ) as solvent. The mass spectra (EI) were run at $70 \mathrm{eV}$ with JEOL JMS600 equipment and/or a Varian MAT 311 A Spectrometer. Elemental analyses (C, H, and N) were carried out at the Microanalytical Center of Cairo University, Giza, Egypt. The results were found to be in good agreement with the calculated values. 4-Aminoantipyrine (1) (mp $106-110^{\circ} \mathrm{C}$ ) was purchased from the Aldrich Company. The dyeing assessment, fastness tests, and color measurements were carried out in El-Nasr Company for Spinning and Weaving El-Mahalla El-Kubra, Egypt.

\subsubsection{Synthesis of (1,5-Dimethyl-3-Oxo-2-Phenyl-2,3-Dihyd-} ro-1H-Pyrazol-4-yl)Carbonohydrazonoyl Dicyanide (2). A well-stirred solution of 4-aminoantipyrine (1.02 g, $5 \mathrm{mmol}$ ) in $2 \mathrm{~N} \mathrm{HCl}(1.5 \mathrm{~mL})$ was cooled in ice salt bath and diazotized with $1 \mathrm{~N} \mathrm{NaNO}_{2}$ solution $(0.35 \mathrm{~g}, 5 \mathrm{mmol}$; in $2 \mathrm{~mL}$ water). The mixture was then tested for complete diazotization using starch iodide paper which gives a weak blue test. If the mixture does not give the test, more sodium nitrite was added dropwise until a positive test is obtained and the color is stable for few minutes. If, on the other hand, a strong test for nitrite is obtained, a few drops of a dilute solution of the base hydrochloride are added until the nitrite test is nearly negative. The above cold diazonium solution was added slowly to a well-stirred solution to malononitrile $(0.33 \mathrm{~g}, 5 \mathrm{mmol})$ in ethanol $(20 \mathrm{~mL})$ containing sodium acetate $(0.43 \mathrm{~g}, 5.2 \mathrm{mmol})$, and the mixture was cooled in an ice salt bath. After the addition of the diazonium salt solution, the reaction was tested for coupling reaction. A drop of the reaction mixture was placed on a filter paper and the colorless ring surrounding the spot dye was treated with a drop of an alkaline solution of a reactive coupler, such as the sodium salt of 3-hydroxy-2-naphthanilide. If unreacted diazonium salt is present, a dye is formed. The presence of unreacted coupler can be determined in a similar manner using a diazonium salt solution to test the colorless ring. After the coupling reaction is complete, the reaction mixture was stirred for 50 minutes at room temperature. The crude product was filtered, dried, and recrystallized from ethanol to give antipyrinylhydrazonomalononitrile (2) (93\%), mp $140^{\circ} \mathrm{C}$; yellowish orange crystals; ${ }^{1} \mathrm{H}-\mathrm{NMR}$ $\left(400 \mathrm{MHz}, \mathrm{DMSO}-d_{6}\right): \delta_{\mathrm{ppm}}, 2.26\left(\mathrm{~s}, 3 \mathrm{H}, \mathrm{CH}_{3}\right), 3.25(\mathrm{~s}, 3 \mathrm{H}$, $\mathrm{N}-\mathrm{CH}_{3}$ ), 7.35-7.56 (m, 5H, Ph), 12.1 (br., s, $\left.1 \mathrm{H}, \mathrm{NH}\right) ; \mathrm{MS}$ $(\mathrm{m} / z, \%): 281\left(\mathrm{M}^{+}+1,4.3\right), 280\left(\mathrm{M}^{+}, 13.4\right), 188(5.2), 91$ (8.1), $56(100.0)$.

5.1.2. General Procedure for the Synthesis of 3-Amino-2-(1,5Dimethyl-3-Oxo-2-Phenyl-2,3-Dihydro-1H-Pyrazol-4-yl) azo-[3-Substituted]-1-yl-Acrylonitriles 3-10. A mixture of 2 $(1.4 \mathrm{~g}, 5 \mathrm{mmol})$ and the appropriate secondary amine, namely, piperidine $(0.49 \mathrm{~mL}, 5 \mathrm{mmol})$, morpholine $(0.43 \mathrm{~mL}$, $5 \mathrm{mmol}), N$-methylglucamine $(0.98 \mathrm{~g}, 5 \mathrm{mmol})$, pyrrolidine 
(0.41 mL, $5 \mathrm{mmol})$, diphenyl amine $(0.85 \mathrm{~g}, 5 \mathrm{mmol})$, ethyl 2-(4-chlorophenylamino)acetate $(1.07 \mathrm{~g}, 5 \mathrm{mmol})$, piperazine $(0.43 \mathrm{~g}, 5 \mathrm{mmol})$, or 1 -phenylpiperazine $(0.81 \mathrm{~g}, 5 \mathrm{mmol})$ in ethanol $(15 \mathrm{~mL})$, was refluxed for $5 \mathrm{~h}$. The reaction mixture was left to cool and the precipitated solid was filtered off, dried, and recrystallized from EtOH/DMF (2:1) mixture to afford the corresponding acyclic enaminonitriles 3-10, respectively.

5.1.3. 3-Amino-2-((1,5-Dimethyl-3-Oxo-2-Phenyl-2,3-Dihydro-1H-Pyrazol-4-yl)Diazenyl)-3-(Piperidin-1-yl)Acrylonitrile (3). Yield (91\%), mp $209^{\circ} \mathrm{C}$; dark green crystals; IR $(\mathrm{KBr}): \dot{v}\left(\mathrm{~cm}^{-1}\right), 3392,3334\left(\mathrm{NH}_{2}\right), 3189(\mathrm{NH}), 2960$ (C-H, stretching), $2171(\mathrm{CN}), 1639(\mathrm{CO}), 1448(\mathrm{~N}=\mathrm{N})$; ${ }^{1} \mathrm{H}-\mathrm{NMR}\left(400 \mathrm{MHz}, \mathrm{DMSO}-d_{6}\right): \delta_{\mathrm{ppm}}, 1.58-1.69(\mathrm{~m}, 6 \mathrm{H}$, $3 \mathrm{CH}_{2}$, piperidine), $2.63\left(\mathrm{~s}, 3 \mathrm{H}, \mathrm{CH}_{3}\right), 3.16\left(\mathrm{~s}, 3 \mathrm{H}, \mathrm{N}-\mathrm{CH}_{3}\right)$, 3.52-3.62 (m, $4 \mathrm{H}, 2 \mathrm{CH}_{2}$, piperidine), 7.13 (br., s, $2 \mathrm{H}, \mathrm{NH}_{2}$ ), 7.31-7.52 (m, 5H, Ph); ${ }^{13} \mathrm{C}-\mathrm{NMR}\left(100 \mathrm{MHz}, \mathrm{DMSO}-d_{6}\right)$ : $\delta_{\mathrm{ppm}}, 173.2\left(\mathrm{C}-\mathrm{NH}_{2}\right), 160.4(\mathrm{CO}), 160.1\left(\underline{\mathrm{C}}-\mathrm{CH}_{3}\right), 136.5$, 129.1, 119.5 (Ar-C), $114.8(\mathrm{CN}), 113.0,95.7$ (C-CN), 46.8, 25.9, $25.7\left(5 \mathrm{CH}_{2}\right.$, piperidine $), 39.8\left(\mathrm{~N}-\mathrm{CH}_{3}\right), 13.1\left(\mathrm{CH}_{3}\right) . \mathrm{MS}$ : $(\mathrm{m} / z, \%) 367\left(\mathrm{M}^{+}+2,2.3\right), 366\left(\mathrm{M}^{+}+1,14.5\right), 338(12.2), 280$ (11.0), 215 (11.0), 189 (77.9), 152 (100.0), 86 (12.8), 63 (26.7). Anal. Calcd. for $\mathrm{C}_{19} \mathrm{H}_{23} \mathrm{~N}_{7} \mathrm{O}$ (365.43): C, 62.45; $\mathrm{H}, 6.34 ; \mathrm{N}$, 26.83\%; Found: C, 62.52; H, 6.38; N, 26.94\%.

5.1.4. 3-Amino-2-((1,5-Dimethyl-3-Oxo-2-Phenyl-2,3-Dihydro-1H-Pyrazol-4-yl)Diazenyl)-3-Morpholinoacrylonitrile (4). Yield (83\%), mp $232^{\circ} \mathrm{C}$; light brown crystals; IR ( $\left.\mathrm{KBr}\right)$ : v́ $\left(\mathrm{cm}^{-1}\right), 3385,3337\left(\mathrm{NH}_{2}\right), 3197(\mathrm{NH}), 2967(\mathrm{C}-\mathrm{H}$, stretching), $2186(\mathrm{CN}), 1637(\mathrm{CO}), 1470(\mathrm{~N}=\mathrm{N}) ;{ }^{1} \mathrm{H}-\mathrm{NMR}$ $\left(400 \mathrm{MHz}, \mathrm{DMSO}-d_{6}\right): \delta_{\mathrm{ppm}}, 2.22-2.25\left(\mathrm{~m}, 4 \mathrm{H}, 2 \mathrm{CH}_{2}\right.$, morpholine), 2.44 (s, 3H, $\left.\mathrm{CH}_{3}\right), 3.10\left(\mathrm{~s}, 3 \mathrm{H}, \mathrm{N}-\mathrm{CH}_{3}\right), 3.58-3.74$ (m, 4H, 2 $\mathrm{CH}_{2}$, morpholine), 7.24 (br., s, $2 \mathrm{H}, \mathrm{NH}_{2}$ ), 7.36-7.51 $(\mathrm{m}, 5 \mathrm{H}, \mathrm{Ph}) ;{ }^{13} \mathrm{C}-\mathrm{NMR}\left(100 \mathrm{MHz}, \mathrm{DMSO}-d_{6}\right): \delta_{\mathrm{ppm}}, 173.2$ $\left(\underline{\mathrm{C}}-\mathrm{NH}_{2}\right), 160.5$ (CO), $160.3\left(\underline{\mathrm{C}}-\mathrm{CH}_{3}\right), 134.5,129.4,119.7$, 123.5, 122.7 (Ar-C), $114.8(\mathrm{CN}), 102.1(\underline{\mathrm{C}}-\mathrm{N}=\mathrm{N}), 95.7$ (C-CN), 64.9, $47.1\left(4 \mathrm{CH}_{2}\right.$, morpholine), $35.8\left(\mathrm{~N}-\mathrm{CH}_{3}\right), 13.1$ $\left(\overline{\mathrm{C}} \mathrm{H}_{3}\right)$. MS $(\mathrm{m} / z, \%): 368\left(\mathrm{M}^{+}+1,6.7\right), 367\left(\mathrm{M}^{+}, 15.5\right), 275$ (7.7), 214 (13.4), 188 (14.6), 108 (24.6), 96 (17.8), 56 (100.0); Anal. for $\mathrm{C}_{18} \mathrm{H}_{21} \mathrm{~N}_{7} \mathrm{O}_{2}$ (367.41): Calcd.: C, 58.84; H, 5.76; N, 26.69\%; Found: C, 58.91; H, 5.83; N, 26.76\%.

5.1.5. 3-Amino-2-((1,5-Dimethyl-3-Oxo-2-Phenyl-2,3-Dihydro-1H-Pyrazol-4-yl)Diazenyl)-3-(Methyl((2S,3R,4R,5R)-2,3, 4,5,6-Pentahydroxyhexyl) Amino)Acrylonitrile (5). Yield (83\%), mp $205^{\circ} \mathrm{C}$; dark yellow crystals; IR (KBr): $v\left(\mathrm{~cm}^{-1}\right)$, 3451, $3436(\mathrm{OH}), 3358,3301\left(\mathrm{NH}_{2}\right), 2954$ (C-H, stretching), $2186(\mathrm{CN}), 1648(\mathrm{CO}), 1459(\mathrm{~N}=\mathrm{N}) ;{ }^{1} \mathrm{H}-\mathrm{NMR}(400 \mathrm{MHz}$, DMSO- $\left.d_{6}\right): \delta_{\mathrm{ppm}}, 2.47\left(\mathrm{~s}, 3 \mathrm{H}, \mathrm{CH}_{3}\right), 3.16\left(\mathrm{~s}, 3 \mathrm{H}, \mathrm{N}-\mathrm{CH}_{3}\right)$, 3.35-3.41 (m, 5H, CH 4.36-5.14 (br, m, 5H, 5OH), 7.33 (br., s, 2H, NH 2 ), 7.35-7.53 $(\mathrm{m}, 5 \mathrm{H}, \mathrm{Ph}) ;{ }^{13} \mathrm{C}-\mathrm{NMR}\left(100 \mathrm{MHz}, \mathrm{DMSO}-d_{6}\right): \delta_{\mathrm{ppm}}$, $173.3\left(\underline{\mathrm{C}}-\mathrm{NH}_{2}\right), 160.6(\mathrm{CO}), 160.1\left(\underline{\mathrm{C}}-\mathrm{CH}_{3}\right), 134.5,129.3$, $119.8(\overline{\mathrm{Ar}}-\mathrm{C}), 114.8(\mathrm{CN}), 102.1(\underline{\mathrm{C}}-\mathrm{N}=\mathrm{N}), 95.7(\underline{\mathrm{C}}-\mathrm{CN})$, 72.9, 72.1, 70.8, 64.9, 51.6 (sugar moiety), 46.8, 39.8, 35.9 $\left(\mathrm{N}-\mathrm{CH}_{3}\right), 13.2\left(\mathrm{CH}_{3}\right)$. MS $(\mathrm{m} / z, \%): 477\left(\mathrm{M}^{+}+2,100.0\right)$,
438 (97.0), 282 (78.8), 279 (48.5), 241 (93.9), 178 (69.7), 163 (57.6), 144 (63.6), 104 (45.5), 94 (15.2), 57 (30.3); Anal. for $\mathrm{C}_{21} \mathrm{H}_{29} \mathrm{~N}_{7} \mathrm{O}_{6}$ (475.50): Calcd.: C, 53.04; H, 6.15; N, 20.62\%; Found: C, 53.12; H, 6.23; N, 20.67\%.

5.1.6. 3-Amino-2-((1,5-Dimethyl-3-Oxo-2-Phenyl-2,3-Dihydro-1H-Pyrazol-4-yl)Diazenyl)-3-(Pyrrolidin-1-yl)Acrylonitr-

ile (6). Yield (88\%), mp $229^{\circ} \mathrm{C}$; light brown sheets; IR ( $\left.\mathrm{KBr}\right)$ : v́ $\left(\mathrm{cm}^{-1}\right), 3367,3272\left(\mathrm{NH}_{2}\right), 3183(\mathrm{NH}), 2944,2875(\mathrm{C}-\mathrm{H}$, aliphatic), $2173(\mathrm{CN}), 1641$ (CO), $1467(\mathrm{~N}=\mathrm{N}) ;{ }^{1} \mathrm{H}-\mathrm{NMR}$ $\left(400 \mathrm{MHz}, \mathrm{DMSO}-d_{6}\right): \delta_{\mathrm{ppm}}, 1.92-2.09\left(\mathrm{~m}, 4 \mathrm{H}, 2 \mathrm{CH}_{2}\right.$, pyrrolidine), $2.44\left(\mathrm{~s}, 3 \mathrm{H}, \mathrm{CH}_{3}\right), 3.10\left(\mathrm{~s}, 3 \mathrm{H}, \mathrm{N}-\mathrm{CH}_{3}\right), 3.50-3.69$ (m, $4 \mathrm{H}, 2 \mathrm{CH}_{2}$, pyrrolidine), 6.73 (br., s, $2 \mathrm{H}, \mathrm{NH}_{2}$ ), 7.31-7.51 $(\mathrm{m}, 5 \mathrm{H}, \mathrm{Ph}) ;{ }^{13} \mathrm{C}-\mathrm{NMR}\left(100 \mathrm{MHz}, \mathrm{DMSO}-d_{6}\right): \delta_{\mathrm{ppm}}, 173.3$ $\left(\mathrm{C}-\mathrm{NH}_{2}\right), 160.5$ (CO), $160.1\left(\mathrm{C}-\mathrm{CH}_{3}\right), 134.8,129.1,129.0$, 119.7, 119.6 (Ar-C), $114.8(\overline{C N}), 102.1(\underline{\mathrm{C}}-\mathrm{N}=\mathrm{N}), 94.2$ ( $\underline{\mathrm{C}}-\mathrm{CN}), 49.6,26.2\left(\mathrm{CH}_{2}\right.$, pyrrolidine $), 13.1\left(\overline{\mathrm{CH}}_{3}\right)$; Anal. for $\overline{\mathrm{C}}_{18} \mathrm{H}_{21} \mathrm{~N}_{7} \mathrm{O}$ (351.41): Calcd.: C, 61.52; H, 6.02; N, 27.90\%; Found: C, 61.58; H, 6.13; N, 27.96\%.

5.1.7. 3-Amino-2-((1,5-Dimethyl-3-Oxo-2-Phenyl-2,3-Dihydro-1H-Pyrazol-4-yl)Diazenyl)-3-(Diphenylamino)Acrylonitrile (7). Yield (75\%), mp $98^{\circ} \mathrm{C}$; light black powder; IR $(\mathrm{KBr})$ : $\dot{v}\left(\mathrm{~cm}^{-1}\right), 3352,3271\left(\mathrm{NH}_{2}\right), 2179(\mathrm{CN}), 1644(\mathrm{CO}), 1472$ $(\mathrm{N}=\mathrm{N}) ;{ }^{1} \mathrm{H}-\mathrm{NMR}\left(400 \mathrm{MHz}, \mathrm{DMSO}-d_{6}\right): \delta_{\mathrm{ppm}}, 2.42(\mathrm{~s}, 3 \mathrm{H}$, $\left.\mathrm{CH}_{3}\right), 3.18$ (s, 3H, N-CH $\left.\mathrm{CH}_{3}\right), 6.63-7.54(\mathrm{~m}, 15 \mathrm{H}, \mathrm{Ar}-\mathrm{H}), 8.14$ (br., s, $\left.2 \mathrm{H}, \mathrm{NH}_{2}\right) ;{ }^{13} \mathrm{C}-\mathrm{NMR}\left(100 \mathrm{MHz}, \mathrm{DMSO}-d_{6}\right): \delta_{\mathrm{ppm}}$, $170.4\left(\mathrm{C}-\mathrm{NH}_{2}\right), 160.4(\mathrm{CO}), 160.1\left(\mathrm{C}-\mathrm{CH}_{3}\right), 140.8,133.5$, $129.6,127.0,124.5,123.5,122.6$ (Ar-C), 114.8 (CN), 101.9 $(\underline{\mathrm{C}}-\mathrm{N}=\mathrm{N}), 94.0(\underline{\mathrm{C}}-\mathrm{CN}), 90.7(\underline{\mathrm{C}}-\mathrm{CN}), 35.2\left(\mathrm{~N}-\mathrm{CH}_{3}\right), 13.3$ $\left(\mathrm{CH}_{3}\right)$; Anal. for $\mathrm{C}_{26} \mathrm{H}_{23} \mathrm{~N}_{7} \mathrm{O}$ (449.51): Calcd.: C, 69.47; H, 5.16; N, 21.81\%; Found: C, 69.52; H, 5.24; N, 21.88\%.

5.1.8. Ethyl 2-((1-Amino-2-Cyano-2-((1,5-Dimethyl-3-Oxo2-Phenyl-2,3-Dihydro-1H-Pyrazol-4-yl)Diazenyl) Vinyl)(4Chlorophenyl) Amino)Acetate (8). Yield (75\%), mp 88-90 C; light black powder; IR (KBr): $v\left(\mathrm{~cm}^{-1}\right), 3358,3266\left(\mathrm{NH}_{2}\right)$, $2183(\mathrm{CN}), 1740(\mathrm{C}=\mathrm{O}$, ester $), 1648(\mathrm{CO}), 1479(\mathrm{~N}=\mathrm{N})$; ${ }^{1} \mathrm{H}-\mathrm{NMR}\left(400 \mathrm{MHz}, \mathrm{DMSO}-d_{6}\right): \delta_{\mathrm{ppm}}, 1.29\left(\mathrm{t}, 3 \mathrm{H}, \mathrm{CH}_{2} \mathrm{CH}_{3}\right.$, $J=7.2 \mathrm{~Hz}), 2.41\left(\mathrm{~s}, 3 \mathrm{H}, \mathrm{CH}_{3}\right), 3.18\left(\mathrm{~s}, 3 \mathrm{H}, \mathrm{N}-\mathrm{CH}_{3}\right), 3.82$ (s, $2 \mathrm{H}, \mathrm{CH}_{2}$ ), 4.12 (q, $2 \mathrm{H}, \mathrm{CH}_{2} \mathrm{CH}_{3}, J=7.2 \mathrm{~Hz}$ ), 6.2 (br, s, 2H, $\mathrm{NH}_{2}$ ), 7.01-8.12 (m, 9H, Ar-H); ${ }^{13} \mathrm{C}-\mathrm{NMR}(100 \mathrm{MHz}$, DMSO- $\left.d_{6}\right): \delta_{\mathrm{ppm}}, 168.2\left(\mathrm{C}-\mathrm{NH}_{2}\right), 168.4(\mathrm{CO}), 161.5(\mathrm{CO})$, $160.5\left(\underline{\mathrm{C}}-\mathrm{CH}_{3}\right), 142.3,136.6,129.7,129.1,129.0,122.8$ $(\mathrm{Ar}-\mathrm{C}), 114.8(\mathrm{CN}), 113.3,113.1,113.0,102.3(\mathrm{C}-\mathrm{N}=\mathrm{N})$, $95.7(\mathrm{C}-\mathrm{CN}), 62.1\left(\mathrm{CH}_{2} \mathrm{CH}_{3}\right), 50.3\left(\mathrm{CH}_{2}-\mathrm{N}\right), 46.8,34.8$ $\left(\mathrm{N}-\mathrm{CH}_{3}\right), 14.8\left(\mathrm{CH}_{2} \underline{\mathrm{C}} \mathrm{H}_{3}\right), 13.1\left(\mathrm{CH}_{3}\right) . \mathrm{MS}(\mathrm{m} / z, \%): 495$ $\left(\mathrm{M}^{+}+1,0.5\right), 447(0.2), 214$ (7.5), 212 (19.6), 141 (33.0), 139 (100.0), 56 (16.0); Anal. for $\mathrm{C}_{24} \mathrm{H}_{24} \mathrm{ClN}_{7} \mathrm{O}_{3}$ (493.95): Calcd.: C, 58.36; H, 4.90; N, 19.85\%; Found: C, 58.44; H, 4.97; N, $19.93 \%$.

5.1.9. 3-Amino-2-((1,5-Dimethyl-3-Oxo-2-Phenyl-2,3-Dihydro-1H-Pyrazol-4-yl)Diazenyl)-3-(Piperazin-1-yl)Acrylonitrile (9). Yield (72\%), mp 89-90 $\mathrm{C}$; dark red powder; IR $(\mathrm{KBr}): \dot{v}\left(\mathrm{~cm}^{-1}\right), 3450,3379\left(\mathrm{NH}_{2}\right), 3159(\mathrm{NH}), 2929(\mathrm{C}-\mathrm{H}$, stretching), $2174(\mathrm{CN}), 1639(\mathrm{CO}), 1494(\mathrm{~N}=\mathrm{N}) ;{ }^{13} \mathrm{C}-\mathrm{NMR}$ 
$\left(100 \mathrm{MHz}, \mathrm{DMSO}-d_{6}\right): \delta_{\mathrm{ppm}}, 173.3\left(\mathrm{C}-\mathrm{NH}_{2}\right), 160.4(\mathrm{CO})$, $160.0\left(\mathrm{C}-\mathrm{CH}_{3}\right), 134.7,129.1,124.7,123.5$ (Ar-C), 114.8 $(\mathrm{CN}), 102.4(\mathrm{C}-\mathrm{N}=\mathrm{N}), 88.7(\underline{\mathrm{C}}-\mathrm{CN}), 50.6,46.8\left(\mathrm{CH}_{2}\right.$, piperazine $), 35.8\left(\mathrm{~N}-\mathrm{CH}_{3}\right), 13.1\left(\mathrm{CH}_{3}\right)$; $\mathrm{MS}(\mathrm{m} / z, \%): 368\left(\mathrm{M}^{+}+2\right.$, 0.4), 343 (1.0), 228 (2.9), 201 (6.9), 189 (10.0), 160 (17.5), 135 (69.5), 73 (100.0), 65 (20.8); Anal. for $\mathrm{C}_{18} \mathrm{H}_{22} \mathrm{~N}_{8} \mathrm{O}$ (366.42): Calcd.: C, 59.00; H, 6.05; N, 30.58\%; Found: C, 59.08; H, 6.13; N, 30.64\%.

5.1.10. 3-Amino-2-((1,5-Dimethyl-3-Oxo-2-Phenyl-2,3-Dihydro-1H-Pyrazol-4-yl)Diazenyl)-3-(4-Phenylpiperazin-1-yl)Acrylonitrile (10). Yield (86\%), mp $230^{\circ} \mathrm{C}$; yellow powder; IR $(\mathrm{KBr}): \dot{v}\left(\mathrm{~cm}^{-1}\right), 3390,3334\left(\mathrm{NH}_{2}\right), 2925,2809(\mathrm{C}-\mathrm{H}$, aliphatic), $2173(\mathrm{CN}), 1610(\mathrm{CO}), 1490(\mathrm{~N}=\mathrm{N}) ;{ }^{1} \mathrm{H}-\mathrm{NMR}$ $\left(400 \mathrm{MHz}, \mathrm{DMSO}-d_{6}\right): \delta_{\mathrm{ppm}}, 2.44\left(\mathrm{~s}, 3 \mathrm{H}, \mathrm{CH}_{3}\right), 3.10(\mathrm{~s}, 3 \mathrm{H}$, $\left.\mathrm{N}-\mathrm{CH}_{3}\right), 3.28-3.36\left(\mathrm{~m}, 4 \mathrm{H}, 2 \mathrm{CH}_{2}\right.$, piperazine $), 3.72-3.82$ ( $\mathrm{m}, 4 \mathrm{H}, 2 \mathrm{CH}_{2}$, piperazine), 6.12 (br., s, $2 \mathrm{H}, \mathrm{NH}_{2}$ ), 6.81-7.53 $(\mathrm{m}, 5 \mathrm{H}, \mathrm{Ph}) ;{ }^{13} \mathrm{C}-\mathrm{NMR}\left(100 \mathrm{MHz}, \mathrm{DMSO}-d_{6}\right): \delta_{\mathrm{ppm}}, 173.2$ $\left(\mathrm{C}-\mathrm{NH}_{2}\right), 160.4(\mathrm{CO}), 160.1\left(\mathrm{C}-\mathrm{CH}_{3}\right), 149.7,136.6$, (ArC-N), 130.2, 129.1, 124.1, 119.7, 118.4 (Ar-C), $114.8(\mathrm{CN})$, 114.4, 114.3, 113.2, 113.1, 113.0, 95.7 (C-CN), 50.6, 47.3, (4C, pipierazine) 46.8, $39.8\left(\mathrm{~N}-\mathrm{CH}_{3}\right), 13.1\left(\mathrm{CH}_{3}\right) ; \mathrm{MS}(\mathrm{m} / z$, \%): $444\left(\mathrm{M}^{+}+2,5.0\right), 375$ (0.4), 228 (46.6), 214 (65.3), 188 (82.4), 162 (59.7), 132 (94.7), 120 (100.0), 99 (67.3), 88 (42.7), 73 (81.9), 66 (24.3); Anal. for $\mathrm{C}_{24} \mathrm{H}_{26} \mathrm{~N}_{8} \mathrm{O}$ (442.52): Calcd.: C, 65.14; H, 5.92; N, 25.32\%; Found: C, 65.22; H, 5.96; N, $25.39 \%$.

\subsection{Dyeing Procedures}

5.2.1. Preparation of Dye Dispersion. The required amount of the dye ( $2 \%$ shade) was dissolved in a suitable solvent (DMF) and added dropwise with stirring to a solution of Dekol-N $\left(2 \mathrm{~g} / \mathrm{dm}^{3}\right)$, an anionic dispersing agent of BASF, then the dye was precipitated in a fine dispersion ready for use in dyeing.

5.2.2. Dyeing of Polyester at $1301^{\circ} \mathrm{C}$ under Pressure Using Fescaben as a Carrier. The dyebath (1:20 liquor ratio) containing $5 \mathrm{~g} / \mathrm{dm}^{3} 5 \mathrm{~g} / \mathrm{dm}^{-3}$ Levegal PT (Bayer) as a carrier and $4 \%$ ammonium sulphatet and acetic acid a $\mathrm{pH}=5.5$ was brought to $60^{\circ} \mathrm{C}$. The polyester fabric was entered at this degree and run for 15 minutes. $2 \%$ dye in the fine dispersion was added, temperature was raised to the boiling point within 45 minutes, dyeing was continued at the boil for about 1 hour, then dyed material was rinsed and soaped with $2 \%$ nonionic detergent to improve rubbing and wet fastness.

5.2.3. Assessment of Color Fastness (Table 2). Fastness to washing, perspiration, light, and sublimation was tested according to the reported methods.

(i) Fastness to Washing. A specimen of dyed polyester fabric was stitched between two pieces of undyed cotton fabric, all of equal diameters, and then washed at $50^{\circ} \mathrm{C}$ for 30 minutes. The staining on the undyed adjacent fabric was assessed according to the following gray scale: 1 (poor), 2 (fair), 3 (moderate), and 4 (good), and 5 excellent. (ii) Fastness to perspiration. The samples were prepared by stitching pieces of dyed polyester fabric between two pieces of undyed cotton fabric, all of equal diameters, and then immersed in the acid medium for 30 minutes. The staining on the undyed adjacent fabric was assessed according to the following gray scale: 1 poor, 2 fair, 3 moderate, 4 good, and 5 excellent. The acid solution $(\mathrm{pH}=3.5)$ contains sodium chloride $10 \mathrm{~g} / \mathrm{L}$, lactic acid $1 \mathrm{~g} / \mathrm{dm} 3$, disodium orthophosphate $1 \mathrm{~g} / \mathrm{dm} 3$, and histidine monohydrochloride $0.25 \mathrm{~g} / \mathrm{dm} 3$.

(iii) Fastness to Rubbing. The dyed polyester fabric was placed on the base of Crocketeer, so that it rests flat on the abrasive cloth with its long dimension in the direction of rubbing. A square of white testing cloth was allowed to slide on the tested fabric back and forth twenty times by making ten complete turns of the crank. For a wet rubbing test, the testing square was thoroughly wet in distilled water. The rest of the procedure is the same as the dry test. The staining on the white testing closed was assessed according to the following gray scale: 1-poor, 2-fair, 3-moderate, and 4-good, and 5-excellent.

(iv) Fastness to Sublimation. Sublimation fastness was measured with an iron tester (Yasuda no. 138). The samples were prepared by stitching pieces of a dyed polyester fabric between two pieces of an undyed polyester, all of equal diameters, and then treated at $180^{\circ} \mathrm{C}$ and $210^{\circ} \mathrm{C}$ for $1 \mathrm{~min}$. Any staining on the undyed adjacent fabric or change in tone was assessed according to the following gray scale: 1-poor, 2-fair, 3moderate, 4-good, and 5-excellent.

(v) Fastness to Light. Light fastness was determined by exposing the dyed polyester on a Xenotest 150 (Original Hanau, chamber temperature $25-30^{\circ} \mathrm{C}$, black panel temperature $60^{\circ} \mathrm{C}$, relative humidity $50-60 \%$, and dark glass (UV) filter system) for 40 hours. The changes in color were assessed according to the following blue scale: 1 -poor, 3 -moderate, 5 -good, and 8 -very good.

5.2.4. Color Assessment. Table 1 reports the color Parameters of the dye fabrics assessed by tristimulus colorimetry. The color parameters of the dyed fabrics were determined on a spectro the multichannel photodetector (model MCPD1110A), equipped with a D65 source and barium sulfate as a standard blank. The values of the chromaticity coordinates luminance factor and the position of the color in the CIELAB color solid are reported.

In this study, the dyeing performance of the prepared dyes $\mathbf{2 - 1 0}$ on polyester fibers has been evaluated. The results are listed in Table 2. Generally, the fastness properties of dyes $\mathbf{2 - 1 0}$ on polyester fibers were studied (Table 2) and it was observed that (a) fastness to washing on polyester fibers is generally acceptable (3-5), according to the International Geometric Gray Scale; (b) these dyeing showed good stability to acid perspiration (rating 4-5); (c) the light fastness ranges are 7-8 on polyester fibers; (d) all of the dyes have acceptable 
fastness to rubbing (4-6) for wet and dry fibers. This may be attributed to good penetration.

\subsection{Biological Activity}

5.3.1. ABTS Antioxidant Screening Assay. Reagents. Vitamin C was obtained from Sigma, 2,2' -azino-bis-(3-ethylbenzthiazoline-6-sulfonic acid) (ABTS) was purchased from Wak, and all other chemicals were of the highest quality available.

For each of the investigated compounds, $2 \mathrm{~mL}$ of ABTS solution $(60 \mu \mathrm{M})$ was added to $3 \mathrm{M} \mathrm{MnO}_{2}$ solution $(25 \mathrm{mg} / \mathrm{mL})$ all prepared in phosphate buffer $(\mathrm{pH} 7$, $0.1 \mathrm{M}$ ). The mixture was shaken, centrifuged, filtered, and the absorbance $\left(A_{\text {control }}\right)$ of the resulting green-blue solution (ABTS radical solution) was adjusted at ca. 0.5 at $\lambda 734 \mathrm{~nm}$. Then, $50 \mu \mathrm{L}$ of $(2 \mathrm{mM})$ solution of the test compound in spectroscopic and grade methanol/phosphate buffer $(1: 1)$ was added. The absorbance $\left(A_{\text {test }}\right)$ was measured and the reduction in color intensity was expressed as \% inhibition. The inhibition for each compound was calculated from

$$
\% \text { Inhibition }=\left[A \text { (control) }-\frac{A \text { (test) }}{A \text { (control) })}\right] \times 100 .
$$

Vitamin $C$ was used as standard antioxidant (positive control). Blank sample was run without ABTS and using methanol/phosphate buffer $(1: 1)$ instead of sample. The negative control sample was run with methanol/phosphate buffer $(1: 1)$ instead of the tested compound [32].

\subsubsection{Cytotoxic Activity [33].}

Materials and Methods. The reagents RPMI-1640 medium (Sigma Co., St. Louis, USA), Foetal Bovine serum (GIBCO, UK), and the cell lines HepG2, WI38, VERO, and MCF-7 obtained from ATCC were used.

Procedure. The stock samples were diluted with RPMI1640 Medium to desired concentrations ranging from 10 to $1000 \mu \mathrm{g} / \mathrm{mL}$. The final concentration of dimethyl sulfoxide (DMSO) in each sample did not exceed $1 \% \mathrm{v} / \mathrm{v}$. The cytotoxic activity of the compounds was tested against Vero cells: cells from the kidney of green monkey; WI: fibroblast cells; HEPGII: Hepatoma cells, and MCF-7: cells from breast cancer. The $\%$ viability of a cell was examined visually. Briefly, cell were batch cultured for $10 \mathrm{~d}$, then seeded in 96-well plates of $10 \times 10^{3}$ cells/well in fresh complete growth medium in 96 -well microtiter plastic plates at $37^{\circ} \mathrm{C}$ for $24 \mathrm{~h}$ under $5 \% \mathrm{CO}_{2}$ using a water jacketed carbon dioxide incubator (Sheldon, TC2323, Cornelius, OR, USA). The medium (without serum) was added and cells were incubated either alone (negative control) or with different concentrations of sample to give final concentrations of 1000 , 500, 200, 100, 50, 20, and $10 \mu \mathrm{g} / \mathrm{mL}$. Cells were suspended in RPMI-1640 medium, 1\% antibiotic-antimycotic mixture $\left(10^{4} \mu \mathrm{g} / \mathrm{mL}\right.$ potassium penicillin, $10^{4} \mu \mathrm{g} / \mathrm{mL}$ streptomycin sulfate, and $25 \mu \mathrm{g} / \mathrm{mL}$ Amphotericin B), and 1\% L-e in 96well flat bottom microplates at $37^{\circ} \mathrm{C}$ under $5 \% \mathrm{CO}_{2}$. After $96 \mathrm{~h}$ of incubation, the medium was again aspirated, trays were inverted onto a pad of paper towels, and the remaining cells rinsed carefully with medium and fixed with $3.7 \%(\mathrm{v} / \mathrm{v})$ formaldehyde in saline for at least $20 \mathrm{~min}$. The fixed cells were rinsed with water and examined. The cytotoxic activity was identified as confluent, relatively unaltered monolayers of stained cells treated with compounds. Cytotoxicity was estimated as the concentration that caused approximately $50 \%$ loss of monolayer. The assay was used to examine the newly synthesized compounds. 5-Fluorouracil was used as a positive control.

\section{Acknowledgment}

Authors thank Professor Dr. Farid A. Badria, Professor of the Pharmacognosy, Faculty of Pharmacy, Mansoura University, for biological activity screening of the tested dyes.

\section{References}

[1] S. Bondock, R. Rabie, H. A. Etman, and A. A. Fadda, "Synthesis and antimicrobial activity of some new heterocycles incorporating antipyrine moiety," European Journal of Medicinal Chemistry, vol. 43, no. 10, pp. 2122-2129, 2008.

[2] E. Abdel-Latif, "Versatile synthesis of N,S-heterocycles containing the antipyrine moiety," Phosphorus, Sulfur and Silicon and the Related Elements, vol. 181, no. 1, pp. 125-139, 2006.

[3] S. Bondock, A. El-Gaber Tarhoni, and A. A. Fadda, "Heterocyclic synthesis with 4-benzoyl-1-cyanoacetylthiosemicarbazide: selective synthesis of some thiazole, triazole, thiadiazine, pyrrylthiazole, and pyrazolo[1,5-a]triazine derivatives," Monatshefte fur Chemie, vol. 139, no. 2, pp. 153-159, 2008.

[4] P. M. Santos, A. M. Antunes, J. Noronha, E. Fernandes, and A. J. Vieira, "Scavenging activity of aminoantipyrines against hydroxyl radical," European Journal of Medicinal Chemistry, vol. 45, no. 6, pp. 2258-2264, 2010.

[5] J. Hosler, C. Tschanz, C. E. Hignite, and D. L. Azarnoff, "Topical application of lindane cream (Kwell) and antipyrine metabolism," Journal of Investigative Dermatology, vol. 74, no. 1, pp. 51-53, 1980.

[6] P. J. Meffin, R. L. Williams, T. F. Blaschke, and M. Rowland, "Application of salivary concentration data to pharmacokinetic studies with antipyrine," Journal of Pharmaceutical Sciences, vol. 66, no. 1, pp. 135-137, 1977.

[7] K. M. Knights, G. K. Gourlay, J. F. Adams, and M. J. Cousins, "A rapid gas-liquid chromatographic determination of antipyrine clearance in the rat," Journal of Pharmacological Methods, vol. 5, no. 2, pp. 121-125, 1981.

[8] S. C. Jain, J. Sinha, S. Bhagat, W. Errington, and C. E. Olsen, "A facile synthesis of novel spiro-[indole-pyrazolinylthiazolidine]-2,4'-dione," Synthetic Communications, vol. 33, no. 4, pp. 563-577, 2003.

[9] V. Cechinel Filho, R. Corrêa, Z. Vaz et al., "Further studies on analgesic activity of cyclic imides," Farmaco, vol. 53, no. 1, pp. 55-57, 1999.

[10] S. M. Sondhi, V. K. Sharma, R. P. Verma et al., "Synthesis, anti-inflammatory and analgesic activity evaluation of some mercapto pyrimidine and pyrimidobenzimidazole derivatives," Synthesis, no. 5, pp. 878-884, 1999.

[11] L. Mishra, "Chelation and fungitoxicity," Journal of the Indian Chemical Society, vol. 76, no. 4, pp. 175-181, 1999. 
[12] N. Raman, A. Kulandaisamyand, and K. Jeyasubramanian, "Synthesis, spectral, redox, and antimicrobial activity of Schiff base transition metal(II) complexes derived from 4-aminoantipyrine and benzil," Synthesis and Reactivity in Inorganic and Metal-Organic Chemistry, vol. 32, no. 9, pp. 1583-1610, 2002.

[13] N. Raman, A. Kulandaisamy, and K. Jeyasubramanian, "Synthesis, structural characterization, redox, and antibacterial studies of 12-membered tetraaza macrocyclic $\mathrm{Cu}(\mathrm{II}), \mathrm{Ni}(\mathrm{II}), \mathrm{Co}(\mathrm{II})$, $\mathrm{Zn}(\mathrm{II})$, and $\mathrm{Vo}(\mathrm{IV})$ complexes derived from 1,2-(diimino4 -antipyrinyl)-1,2-diphenylethane and o-phenylenediamine," Synthesis and Reactivity in Inorganic and Metal-Organic Chemistry, vol. 34, no. 1, pp. 17-43, 2004.

[14] S. M. Sondhi, N. Singhal, R. P. Verma, S. K. Arora, and S. G. Dastidar, "Synthsis of hemin and porphyrin derivatives and their evaluation for anticancer activity," Indian Journal of Chemistry Section B, vol. 40, no. 2, pp. 113-119, 2001.

[15] P. G. Sushama and M. Alaudeen, "Synthetic, spectral and antibacterial studies of $\mathrm{Co}$ (III) and $\mathrm{Mn}$ (III) metal chelates of 2,5-dihydroxy undecyl 1,4-benzoquinone and its Azo derivatives," Asian Journal of Chemistry, vol. 15, no. 1, pp. 366-372, 2003.

[16] A. Pohlmann, W. W. Stamm, H. Kusakabe, and M. R. Kula, "Enzymatic determination of L-lysine by flow-injection techniques," Analytica Chimica Acta, vol. 235, no. 2, pp. 329-335, 1990.

[17] A. Maquestiau and J. Vanden Eynde, Bulletin des Sociétés Chimiques Belges, vol. 95, no. 8, pp. 641-648, 1986.

[18] G. E. H. Elgemeie and F. A. M. Abd El Aal, Heterocycles, vol. 24, no. 2, pp. 349-353, 1986.

[19] M. H. Elnagdi, H. A. Elfahham, M. R. H. Elmoghayar, K. U. Sadek, and G. E. H. Elgemeie, "Reactions with heterocyclic diazonium salts: novel synthesis of pyrazolo[4,3-c]pyridazines and of pyrazolo[4,3-c]pyrazoles," Journal of the Chemical Society, Perkin Transactions, vol. 1, no. 4, pp. 989-991, 1982.

[20] A. A. Fadda, H. A. Etman, F. A. Amer, M. Barghout, and K. S. Mohamed, "Azo disperse dyes for synthetic fibres-2: benzimidazole derivatives," Journal of Chemical Technology and Biotechnology, vol. 62, no. 2, pp. 165-169, 1995.

[21] A. A. Fadda, H. A. Etman, S. E. El-Desoky, and S. Bondk, "Azo disperse dyes for synthetic fibres-IV: indole derivatives," Journal of Chemical Technology and Biotechnology, vol. 64, no. 4, pp. 393-397, 1995.

[22] A. A. Fadda, M. M. Ali, A. S. El-Ahl, and A. Fouda, "Syntheses of 3-aryl-5-[6-(alpha-picolyl)]rhodanines and 3-aryl-5-(2pyridylmethylene)rhodanines and their dyeing performance on acetate and/or other fibres," Indian Journal of Fibre \& Textile Research, no. 18, pp. 151-155, 1993.

[23] A. A. Fadda, H. A. Etman, M. M. Ali, and A. Fouda, "Syntheses of 3-aryl-5-(2-quinolyl)rhodanines 2-arylimino3-(m-methoxyphenyl)-5-(2-quinolyl)rhodanines and 1-aryl-2methyl-4-(2-quinolylidene)imidazol-5-ones and their dyeing performance on acetate and/or other fibres," Indian Journal of Fibre \& Textile Research, vol. 20, no. 1, pp. 34-42, 1995.

[24] A. A. Fadda, H. A. Etman, F. A. Amer, M. Barghout, and K. M. Samir, "Azo disperse dyes for synthetic fibres-3: 2styrylquinazolone derivatives," Journal of Chemical Technology and Biotechnology, vol. 62, no. 2, pp. 170-176, 1995.

[25] A. M. Khalil, M. A. Berghot, and M. A. Gouda, "Synthesis and antibacterial activity of azodispersed dyes incorporating a phthalazinedione moiety for dyeing polyester fabrics," Monatshefte fur Chemie, vol. 140, no. 11, pp. 1371-1379, 2009.
[26] A. M. Khalil, M. A. Berghot, M. A. Gouda, and S. A. El Bialy, "Synthesis and antibacterial studies of azodispersed dyes derived from 2-(thiazol-2-yl)phthalazine-1,4-diones," Monatshefte fur Chemie, vol. 141, no. 12, pp. 1353-1360, 2010.

[27] E. Abdel-Latif and F. A. Amer, "Synthesis of some 4-arylazo3-hydroxythiophene disperse dyes for dyeing polyester fabrics," Monatshefte fur Chemie, vol. 139, no. 5, pp. 561-567, 2008.

[28] V. Kryštof, P. Cankař, I. Fryšová et al., “4-Arylazo-3,5-diamino$1 \mathrm{H}$-pyrazole CDK Inhibitors: SAR study, crystal structure in complex with CDK2, selectivity, and cellular effects," Journal of Medicinal Chemistry, vol. 49, pp. 6500-6509, 2006.

[29] A. A. Fadda, S. S. Elmorsy, A. M. El-Sayed, A. M. Khalil, and S. A. Elagazy, Indian Journal of Fibre \& Textile Research, vol. 15, p. 190, 1990.

[30] Society of Dyes Colourists, Standard Methods for the Determination of Colour Fastness of Textiles and Leather, Society of Dyes and Colourists, Bradfo, Pa, USA, 5th edition, 1990.

[31] E. A. Lissi, B. Modak, R. Torres, J. Escobar, and A. Urzua, “Total antioxidant potential of resinous exudates from Heliotrapium species, and a comparison of the ABTS and DPPH methods," Free Radical Research, vol. 30, no. 6, pp. 471-477, 1999.

[32] A. B. A. El-Gazzar, M. M. Youssef, A. M. S. Youssef, A. A. AbuHashem, and F. A. Badria, "Design and synthesis of azolopyrimidoquinolines, pyrimidoquinazolines as anti-oxidant, antiinflammatory and analgesic activities," European Journal of Medicinal Chemistry, vol. 44, no. 2, pp. 609-624, 2009.

[33] S. Bondock, S. Adel, H. A. Etman, and F. A. Badria, "Synthesis and antitumor evaluation of some new 1,3,4-oxadiazole-based heterocycles," European Journal of Medicinal Chemistry, vol. 48, pp. 192-199, 2012. 

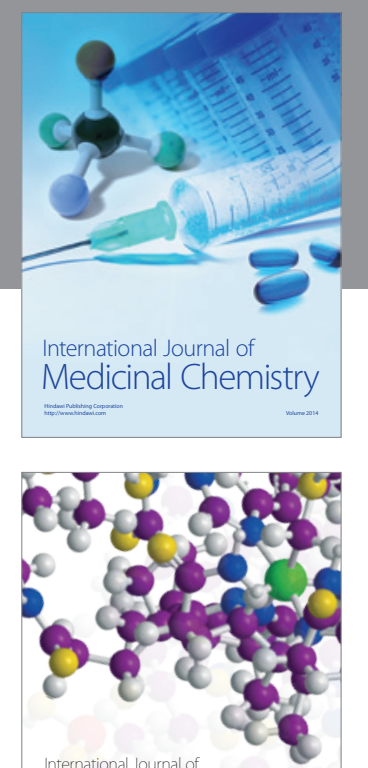

\section{Carbohydrate} Chemistry

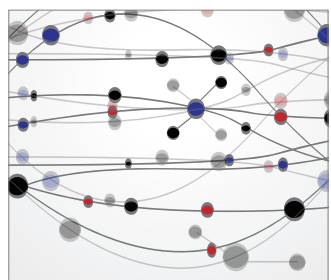

The Scientific World Journal
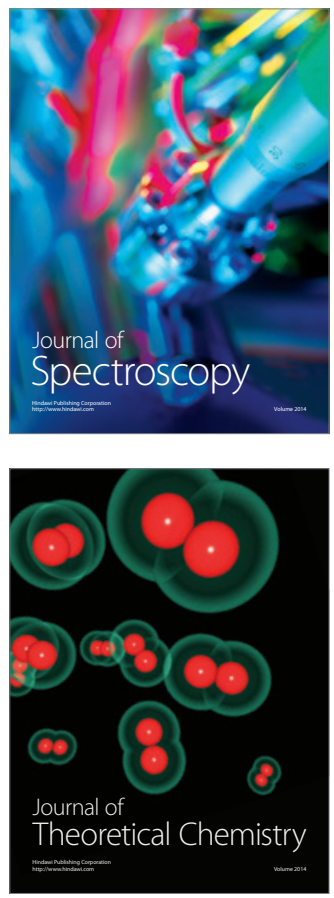
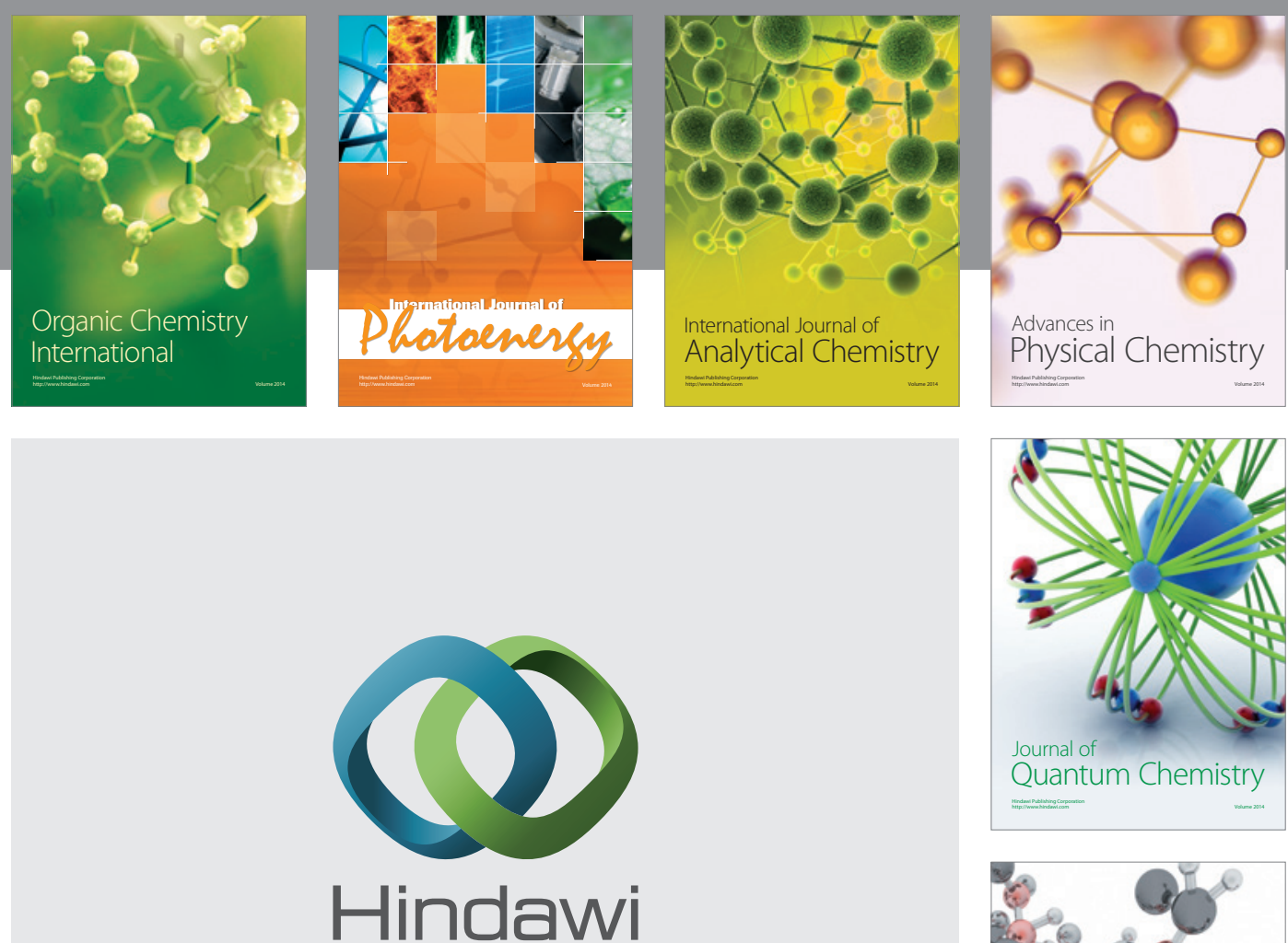

Submit your manuscripts at

http://www.hindawi.com

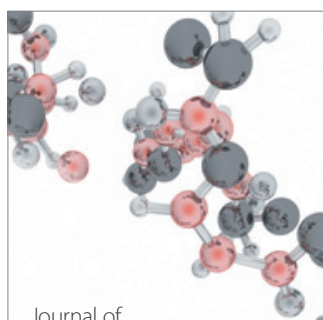

Analytical Methods

in Chemistry

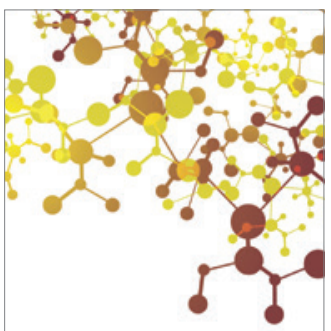

Journal of

Applied Chemistry

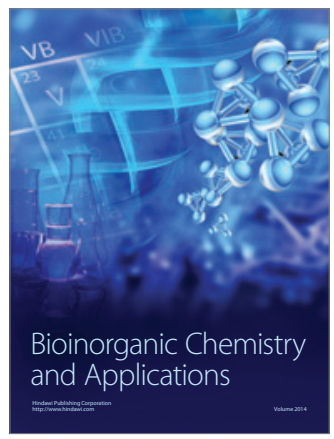

Inorganic Chemistry
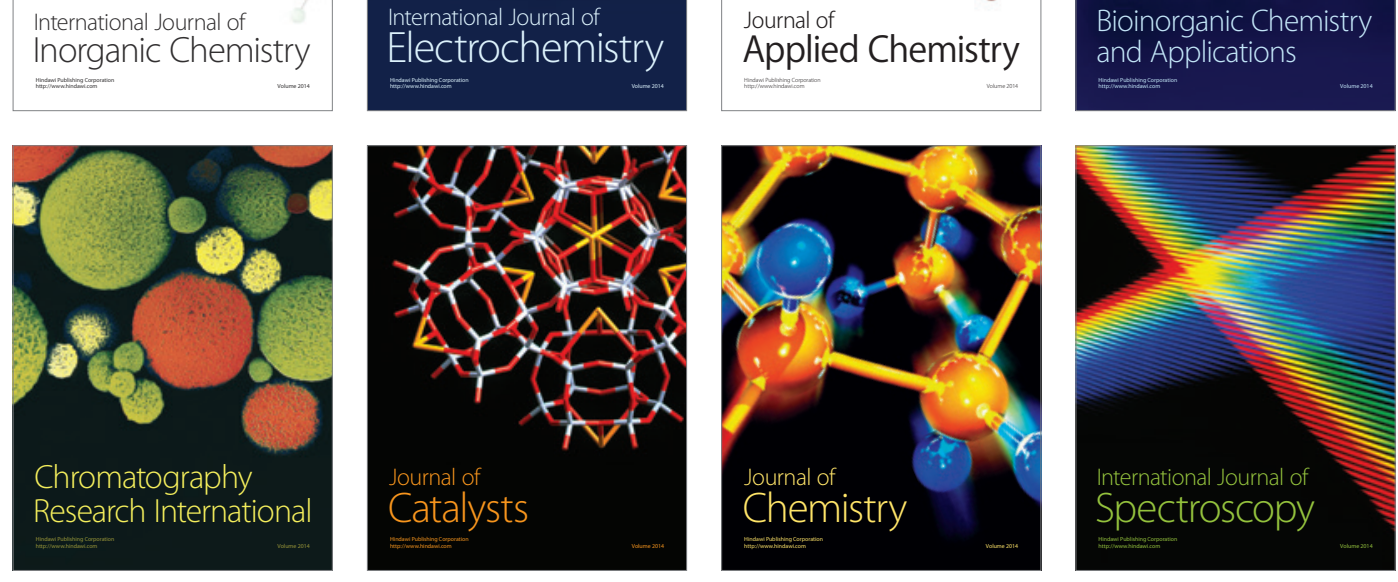